\title{
CHROMOPHORE POLING IN THIN FILMS OF ORGANIC GLASSES. 2. TWO-ELECTRODE CORONA DISCHARGE SETUP
}

\author{
O. Vilitis, I. Muzikante, M. Rutkis, A. Vembris \\ Institute of Solid State Physics, University of Latvia, \\ 8 Ķengaraga Str., Riga, LV-1063, LATVIA
}

\begin{abstract}
In Part 1 of the article we provided description of the corona discharge physics and overview of the methods used for corona poling in thin organic films. Subsequent sections describe comparatively simple technical methods for poling the organic nonlinear optical polymers using a two-electrode (point-to-plate or wire-toplate) technique. The polarization build-up was studied by the DC positive corona method for poling the nonlinear optical (NLO) polymers. The experimental setup provides the corona discharge current from $0.5 \mu \mathrm{A}$ up to $3 \mu \mathrm{A}$ by applying $3 \mathrm{kV}-$ $12 \mathrm{kV}$ voltage to the corona electrode and makes possible selection among the types of corona electrodes (needle, multi-needle, wire, etc.). The results of experimental testing of the poling setup show that at fixed optimal operational parameters of poling - the sample orientation temperature and the discharge current - the corona charging of polymeric materials can successfully be performed applying the twoelectrode technique. To study the dynamics of both poling and charge transport processes the three-electrode charging system - a corona triode - should be applied.
\end{abstract}

Key words: corona discharge, corona poling, poled polymer.

\section{INTRODUCTION}

In a nonlinear optical (NLO) material the polar moieties should be acentrically aligned (poled), which is generally achieved by applying electric poling field. The nonlinear susceptibility of the material depends on the degree of chromophore alignment and, therefore, on the poling field strength. One of the simplest methods to achieve a high magnitude of the poling field is to charge a thin film's surface by two-electrode corona poling. In this case the corona discharge system has a twoelectrode arrangement comprising a corona electrode, a sharp needle made of thin wire $(5-20 \mu \mathrm{m}$ in diameter) placed at a distance of one to several $\mathrm{cm}$ from the grounded opposite electro-conducting planar electrode with a previously placed thin NLO polymer film.

If the voltage applied to such a two-electrode system is high enough, the ions from the plasma region nearby the corona electrode are following the electric field lines to a sample's films. On the film surface a free surface charge accumulates, which produces field inside the sample. Due to the difference of potentials and the conductivity of the sample, the electronic current is flowing through the bulk of this sample. The positive ions accumulated on the sample's surface are neutralized by electrons and leave it as neutral atoms or molecules. Non-neutralized excessive ions either reside on the surface or are injected into the bulk [1]. The ionic current 
generated by corona discharge becomes equal to the electronic conduction current flowing through the sample, and the surface voltage reaches a steady-state value. This reduces the discharge voltage in the gap between electrodes, thus decreasing the discharge current. The current control circuit changes the discharge current and automatically raise the output voltage of the high-voltage power supply (HVPS) until the pre-set current value is restored.

For serial samples poled at different stabilized current values the optimal corona discharge current can be determined by optical nonlinearity measurements. Therewith, the control of corona discharge current allows an easy setting of the desirable corona discharge mode for producing the poled polymeric thin films. At the same time, this method does not allow obtaining the value of the sample surface charge $[2,3]$. Therefore, it is impossible to normalize the achieved NLO efficiency to the poling field. In a typical situation, when the samples have different thickness/conductivity - and, therefore, poling field to be applied - such normalized to the field strength NLO efficiencies should be used for objective comparison of the poled NLO polymer materials.

We present here a continuation (Part 2) of article [4], which contained description of the corona discharge physics and overview of the methods used for corona poling in thin organic films.

\section{EXPERIMENTAL SETUP}

Schematic drawing of a simple experimental setup used in our measurements for poling polymeric thin films is shown in Fig. 1. In its simplified configuration, the two-electrode corona charging unit consists of two basic components: a planar conductive opposite electrode (transparent thin indium-tin oxide (ITO) or Au film placed on a $\sim 1 \mathrm{~mm}$ thick glass substrate), and a corona electrode.

The thin film to be oriented is deposited on the substrate. The polymer sample films ( 1 $\mu \mathrm{m}$ thick) are spin-coated directly on the thin ITO films. The bare surface of glass substrate is tightly pressed to the polished area of thermally conductive heating platform - a cooper block warmed by heater. Its temperature is programmable and controlled by a platinum Pt100 thermo-sensor. The latter is isolated from the corona discharge space and positioned on the $1 \mathrm{~mm}$ thick separate glass substrate in a thermal contact with the copper block surface. Another design of the charging unit allows poling under the conditions when the sample is deposited on one surface of a glass substrate directly while the opposite electrode is deposited on its other surface.

The other basic component - the corona electrode (see Fig. 1) - consists of a $20 \mu \mathrm{m}$ wolfram wire placed above the sample in parallel to its surface. The corona electrode holder has a clamp for using different electrode modifications. The holder is centred in a Plexiglas cylinder with a screw coupling, which allows changing the location distance $(1-5 \mathrm{~cm})$ above the opposite electrode. The Plexiglas cylinder together with a Teflon base cylinder separates the corona discharge space from the environment. The Plexiglas cylinder is equipped with an opening for gas inlet when operating in nitrogen $\left(\mathrm{N}_{2}\right)$ or other gaseous media (not shown in the figure).

A grounded metallic mask ring and a Teflon screen ring are both placed close to the sample's surface (Fig. 1) and act as a shield limiting the poling area of a sample's surface. 


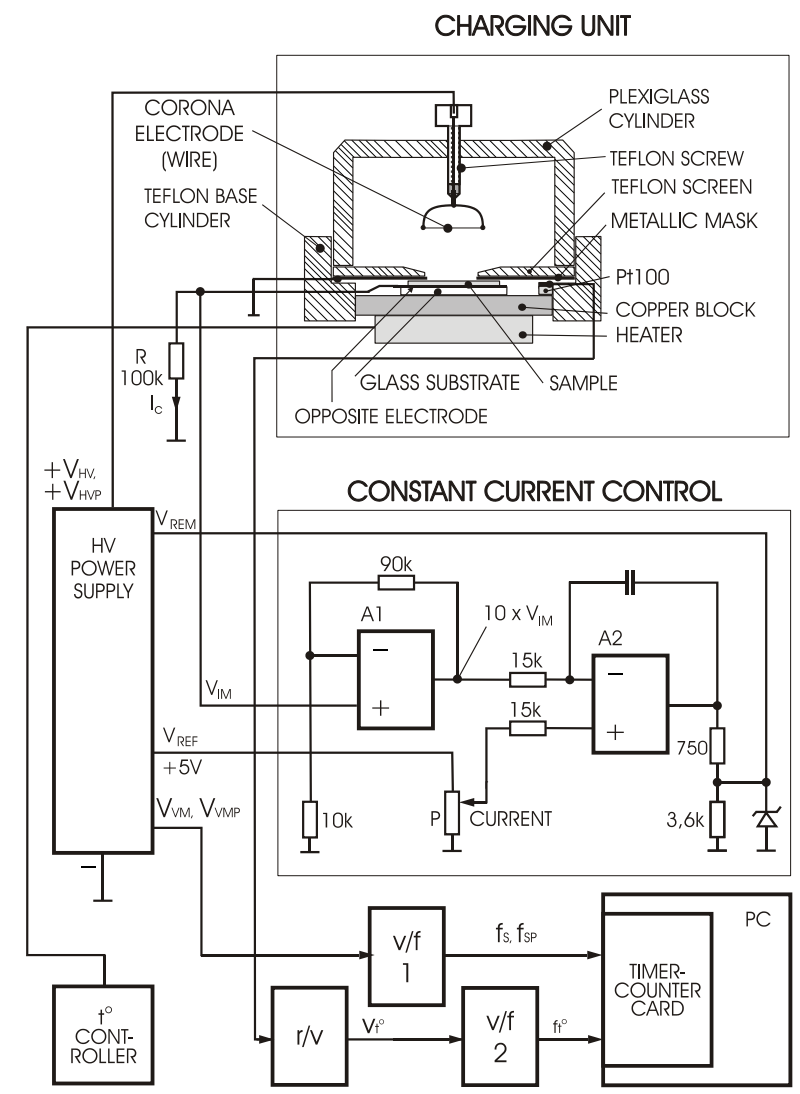

Fig. 1. Schematic of the experimental setup for poling polymeric thin films.

To feed the corona discharge channel a high-voltage power supply (HVPS) unit was used. The positive output of the HVPS unit is connected to the respective corona electrode - the wire (the negative outputs are described below). As HVPS, in the setup a 20A12-P4-C "ULTRAVOLT" unit was used. Apart from a highvoltage remote control $\left(\mathrm{V}_{R E M}\right)$ input channel, such HVPS is provided with a highvoltage monitoring $\left(\mathrm{v}_{V M}\right)$ output channel (see Fig. 1) and a HVPS current monitoring output channel. However, the use of this monitoring channel for stabilizing the small corona current $(0.5-3 \mu \mathrm{A})$ is confusing, since voltage $\mathrm{v}_{I M}$ is proportional to the sum of the corona current and the current through the resistors of HVPS internal divider (the HVPS internal feedback resistors and internal testpoint resistors). For the chosen HVPS the current through resistors may reach $40 \mu \mathrm{A}$. To set the voltage supply for a constant stabilized corona charging current which provides the required accuracy of monitoring, the opposite electrodes are connected to the grounded negative outputs of the HVPS unit through resistors R (as shown in Fig. 1). Their resistance (of $100 \mathrm{k} \Omega$ ) is small in comparison with the total resistance of the discharge channel's circuit. Voltage drop $\mathrm{v}_{I M}$ over resistance $\mathrm{R}$ characterizes corona current $I_{c}$ in the sample circuit with the monitor scale factor of $0.1 \mathrm{~V} / 1 \mu \mathrm{A}$. A simple current regulator circuit added to the HVPS unit enables setting the current $I_{c}$ within the range of $0.5-3 \mu \mathrm{A}$ and automatically keeps it constant during the poling of polymer samples. 
The electronic circuit of the charging unit's current control consists of two amplifiers, A1 and A2 (in a micro-power quad LP324 amplifier) with A1 being a non-inverting voltage amplifier from whose output the tenfold raised $\mathrm{v}_{I M}$ is applied to the A2 inverting input. For example, at $I_{c}=1 \mu \mathrm{A}$ it is $1 \mathrm{~V}$, and further is compared with a corresponding adjustable positive reference voltage at the A2 non-inverting input. Its output voltage is applied to the HVPS "remote adjust" input $\mathrm{v}_{R E M}$, which causes a current build-up in the control feedback circuit (Fig. 1). The A2 device compares the amplified voltage drop of charging current on the resistor R with the reference signal and controls the HVPS "remote adjust" voltage. For example, if current in the corona discharge circuit drops below the pre-set value, voltage $\mathrm{v}_{H V}$ increases (and vice versa), maintaining a constant corona current. As reference, $+5 \mathrm{~V}$ voltage at the HVPS output was used. The constant current is set by potentiometer $\mathrm{P}$.

To register the feeding high voltage $\left(+\mathrm{v}_{H V}\right)$ of corona electrode, the HVPS voltage monitoring outputs $\left(\mathrm{v}_{V M}\right)$ are used with the monitoring scale factor $\mathrm{k}(\mathrm{k}=$ $1 / 1000)$. This voltage signal is converted into a pulse signal $f_{s}$ by a voltage-tofrequency converter $(v / f(1)$ in the figure).

For recording the temperature a Pt100 thermo-sensor was taken. The sensor's resistance (which is proportional to the sample's temperature) is converted into voltage $\mathrm{v}_{t^{\circ}}$ by a resistance-to-voltage converter $(r / v)$. This voltage signal is converted into a pulse signal $f_{t^{\circ}}$ by the voltage-to-frequency converter $v / f(2)$.

The frequencies $f_{s}$ and $f_{t}$ at the output of converters are proportional to the respective input voltage. To integrate and record the $f_{s}$ and $f_{t}$ values, a PC ISA bus multi-channel timer-counter card is employed (Fig. 1). Counting the output pulses at preset time intervals allows obtaining signals continuously integrated with respect to time. The input signal values are calculated from the $v / f$ conversion factors and integration time.

\section{EXPERIMENTAL RESULTS}

The two-electrode corona poling setup described above has been successfully used for practical poling of polymer samples and acquiring NLO active thin films [5-10]. At the same time, uncertainty in control of the sample surface charge build-up is typical for a setup of the kind, and, therefore, the poling field strength remains unknown. Due to this, one of the important characteristics of NLO material performance - that is, the normalized to poling field NLO coefficient - could not be obtained. In this case, optimization of poling parameters (e.g. the poling temperature) becomes problematic. As an example we will present an attempt to optimize the poling parameters for a particular Host/Guest polymer system.

The doped polymer film samples consisting of polymethylmethacrylate (PMMA) as matrix and dimethylaminobenzylidene 1,3-indandione (DMABI) as polar nonlinear active molecules were spin-coated onto ITO glass. The $3 \mathrm{wt} \%$ load of DMABI molecules in PMMA was chosen to avoid polar molecule aggregation in the system (for details of the sample preparation procedure see, e.g., [7]). The corona poling of all samples was performed in three steps. The first one was heating to the desired poling temperature, then a constant current corona discharge was applied for $10 \mathrm{~min}$; finally, the samples were cooled to RT with the corona discharge on. The efficiency of corona poling procedure was characterized by 
measuring the $2^{\text {nd }}$ harmonic generation (SHG) coefficients of the sample. Description of the experimental setup for SHG measurements and determination of relevant coefficients can be found in [8].

To choose the optimal corona current we poled four identical samples with $0.5,1,1.5$ and $2 \mu \mathrm{A}$ constant current values at $100^{\circ} \mathrm{C}$. If our system is considered as two serial resistors (the corona discharge plus the thin film), in the case of higher corona current we should obviously expect a higher voltage drop over the thin polymer film. This means a higher surface charge (poling field) and, therefore, would result in a higher NLO performance of the poled film. However, this was not a case of the kind - the measured SHG coefficients were similar within the experimental error. To analyze this result we will consider the poling dynamics of voltage changes on the corona electrode (Fig. 2).

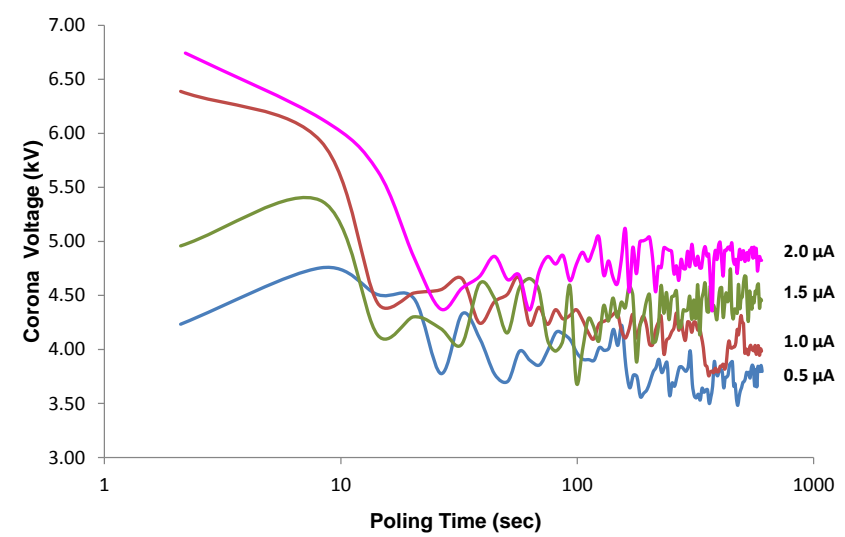

Fig. 2. Corona voltage on the corona electrode in the constant current mode during sample poling.

At the beginning of poling, considerable variations in the corona electrode voltage take place, and then its value saturates to the extent which somehow correlates with the set value of constant corona current. On a closer look on the corona saturation voltage (Fig. 3) it is clear that our system is not ohmic; in other words, the film acts as a surface charge limiter. Increasing the corona current from $0.5 \mu \mathrm{A}$ to $2.0 \mu \mathrm{A}$ enhances the corona saturation voltage only by $30 \%$.

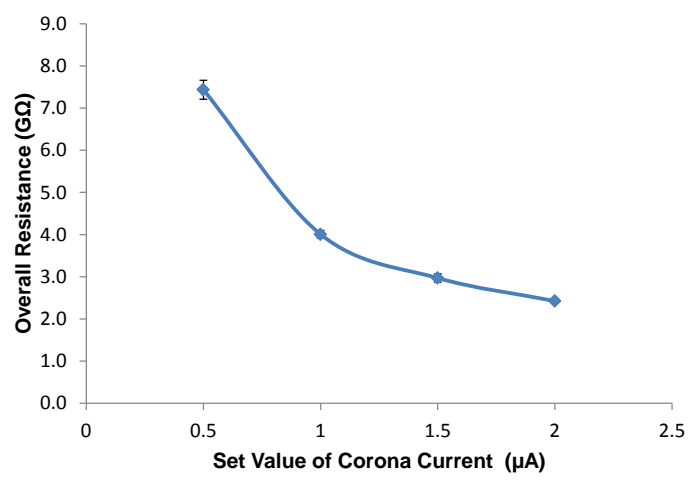

Fig.3. Overall discharge channel and polymer film resistance as function of the set value of corona current. 
One of the explanations for that could be the formation of local conductive channels leading to a partial breakdown of the sample film within the very first moments of charging. If so, the fast initial drop of corona voltage is a result of the film resistivity reduction by these additional conducting channels. Such sample damage is more pronounced under the conditions when the poling is done with a higher constant corona current and therefore a higher corona voltage is required. It is worth mentioning that these channels degrade the overall optical quality of poled films. Because of that and due to the fact that increased corona current gives us no gain in the NLO efficiency, we consider $0.5 \mu \mathrm{A}$ as optimal.

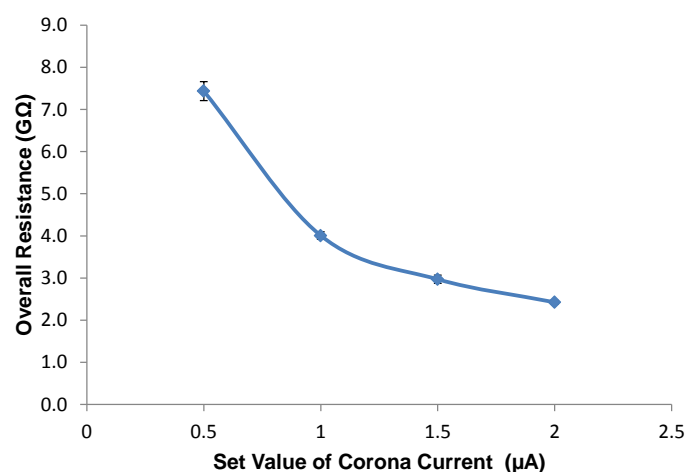

Fig.3. Overall dischsrge channel and polymer film resistance as function of the set value of corona current.

The next parameter to optimize - with a view to achieve the highest polar orientation of chromophores in the matrix - is the orientation temperature. This point is clarified in Fig. 4.

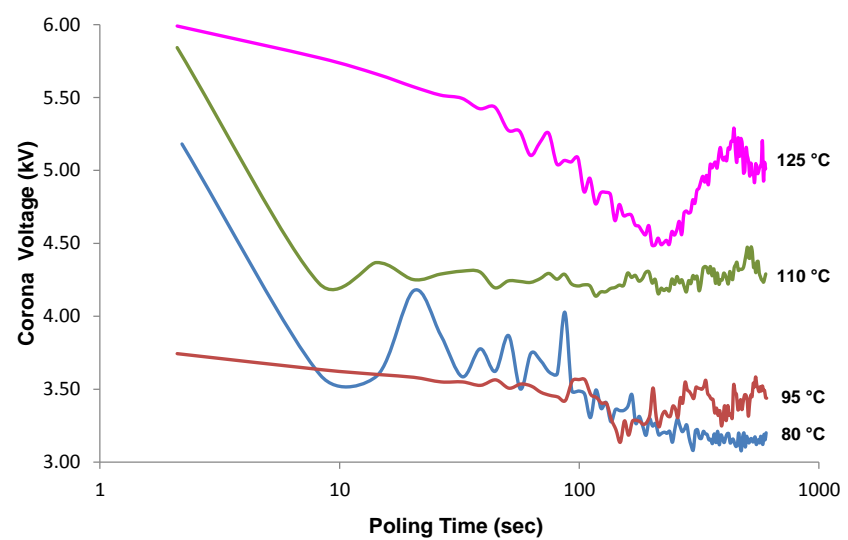

Fig. 4. Corona voltage on the corona electrode in the constant current mode during chromophore orientation at four different temperatures.

Four samples (similar to those used in the previous optimization step) were poled at temperatures $80,95,110$ and $125^{\circ} \mathrm{C}$ with the corona current of $0.5 \mu \mathrm{A}$. First two values are definitely below the glass transition temperature $\left(117^{\circ} \mathrm{C}\right)$ of the material under investigation. The next two are close to $\mathrm{T}_{\mathrm{g}}$ (below and above the mentioned temperature to the same extent). For PMMA-based guest/host systems the conductivity typically increases with temperature. Especially steep rise in 
conductivity takes place around the glass transition temperature [11]. In compliance with this, at higher temperatures we need a lower potential to drive the same current through the film. In contradiction to this, in our experiments a higher saturation voltage was observed for a higher poling temperature, i.e. the film resistance is seemingly increasing with temperature (see Fig. 5). One of the possible explanations of this phenomenon is given below.

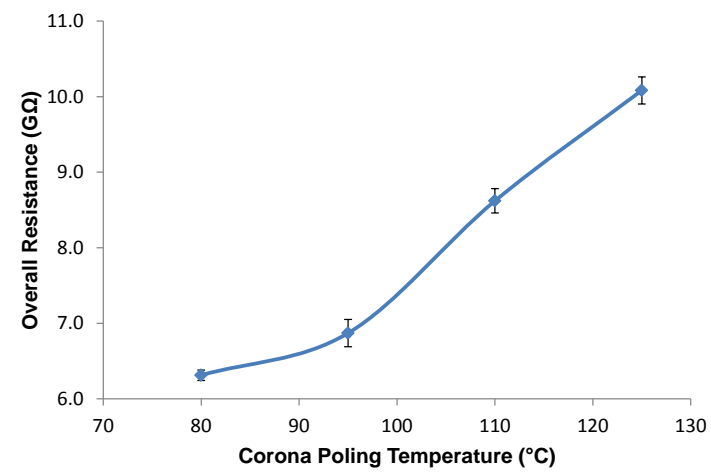

Fig. 5. Overall discharge channel and polymer film resistance $v s$. the corona poling temperature.

For the mentioned above increase in the corona saturation voltage a significantly higher NLO efficiency could be expected. The NLO coefficients $\left(d_{33}, d_{31}\right.$ and $\mathrm{d}_{15}$ ) obtained for the samples poled at different temperatures are presented in Table 1. In the table we included the $d_{33} / d_{31}$ ratio, which characterizes the chromophore polar order and is widely used as the measure of poling efficiency.

NLO coefficients of the samples poled at different temperatures

\begin{tabular}{|c|c|c|c|c|}
\hline $\begin{array}{c}\text { Poling } \mathrm{T} \\
\left({ }^{\circ} \mathrm{C}\right)\end{array}$ & $\begin{array}{c}\mathrm{d}_{15} \\
(\mathrm{pm} / \mathrm{V})\end{array}$ & $\begin{array}{c}\mathrm{d}_{31} \\
(\mathrm{pm} / \mathrm{V})\end{array}$ & $\begin{array}{c}\mathrm{d}_{33} \\
(\mathrm{pm} / \mathrm{V})\end{array}$ & $\mathrm{d}_{33} / \mathrm{d}_{31}$ \\
\hline 80 & $0.89 \pm 0.27$ & $0.93 \pm 0.33$ & $1.43 \pm 0.61$ & 1.53 \\
\hline 95 & $0.70 \pm 0.16$ & $0.78 \pm 0.04$ & $1.15 \pm 0.64$ & 1.47 \\
\hline 110 & $0.91 \pm 0.08$ & $0.98 \pm 0.03$ & $2.05 \pm 0.43$ & 2.10 \\
\hline 125 & $0.58 \pm 0.05$ & $0.61 \pm 0.02$ & $1.33 \pm 0.34$ & 2.17 \\
\hline
\end{tabular}

At $110{ }^{\circ} \mathrm{C}$ only a slight increase in the poling (NLO) efficiency takes place. Further increase in the temperature above that of glass transition $\left(125^{\circ} \mathrm{C}\right)$ causes some decrease in the overall NLO efficiency. At the same time, ratio $d_{33} / d_{31}$ is significantly greater for higher poling temperatures. The increased polar order along with reduced NLO efficiency can be explained by loss of active chromophores from PMMA matrix at the temperatures over that for glass transition. Such being the case, this decrease in the chromophore concentration could be a reason for the mentioned increase in the resistance of guest/host system.

\section{CONCLUSIONS}

In order to obtain the $2^{\text {nd }}$ second order nonlinear optical activity of polymeric materials the corona charging can successfully be performed using the point-to- 
plane two-electrode technique. As is indicated in our poling optimization example, the charge transport properties of polymer film can be the main factor determining the quality of poling. Therefore, simultaneous dynamic studies of the surface charge build-up and the charge transport through such a film are essential for further development of polymer NLO material poling. For additional control and to obtain more information about these processes, a three-electrode charging system a corona triode - was proposed and built. The description of a corresponding setup as well as the results of our investigations for the same NLO active guest/host system will be presented in upcoming issues of this journal.

\section{ACKNOWLEDGEMENTS}

This work has been supported by the ERDF project

(agreement No. 2010/0308/2DP/2.1.1.1.0/10/APIA/VIAA/051).

\section{REFERENCES}

1. Fedosov, S.N., \& Sergeeva, A.E. (2002). Corona poling of ferroelectric and nonlinear optical polymers. Moldavian J. Phys. Sci., (2), 28-31.

2. Giacometti, J.A., Fedosov, S., \& Costa, M.M. (1999). Corona charging of polymers: Recent advances on constant current charging. Brazilian J. Phys., 29 (2), 269-279.

3. Fedosov, S.N., Sergeeva, A.E., Giacometti, F.A., \& Polischuk S.G. (2002). Switching of polarization and relaxation phenomena in corona poled ferroelectric polymers Physics and Chemistry of Solid State, 3, 413-417.

4. Vilitis, O., Fonavs, E., \& Rutkis, M. (2011). Chromofore poling in thin films of organic glasses. 1. Overview of corona discharge application. Latv. J. Phys. Tec. Sci., 6, 53-65

5. Rutkis, M., Vembris, A., Zauls, V., Tokmakovs, A., \& Fonavs, E. (2006). Novel second-order nonlinear optical polymer materials containing indandione derivatives as cromophores, SPIE Proceedings, Organic Optoelectronics and Photonics (eds. P.L. Heremans, M. Muccini, \& A. Meulenkamp), 6192, 6192Q.

6. Rutkis, M., Vembris, A., Zauls, V., Tokmakovs, A., Fonavs, E. (2007). Non-linear optical properties of polymer systems with poled indandione derivatives as chromophore. Nonlinear optics, quantum optics, 7 (1/3), 31-42.

7. Vembris A., Rutkis M., \& Laizane E., (2008). Effect of corona poling and thermocycling sequence on NLO properties of the guest-host system Molecular Crystals and Liquid Crystals, 485, 873-880.

8. Vembris, A., Rutkis, M., Zauls, V., \& Laizane, E. (2008). Stability of the NLO Polymers - Optical Induced De-poling of the DMABI Molecules in sPMMA. Matrix. Thin Solid Films, 516 (24), 8937-8943.

9. Jecs, E., Kreicberga, J., Kampars, V., Jurgis, A., \& Rutkis, M. (2009). Novel azobenzene precursors for NLO active polyuretanes: Synthesis, quantum chemical and experimental characterization. Optical Materials, 31, 1600-1607.

10. Rutkis, M., Tokmakovs, A., Jecs, E., Kreicberga, J., Kampars, V., \&.Kokars, V. (2010). Indandione based binary chromophore supramolecular systems as a NLO active polymer composites. Optical Materials, 32, 796-802.

11. Dalton, L., Harper, A., Ren, A., Wang, F., Todorova, G., Chen, J., Zhang, C., \& Lee, M. (1999). Ind. Eng. Chem. Res., 38, 8-33. 
HROMOFORU POLARIZĒŠANA PLĀNĀS ORGANISKO STIKLU KĀRTIŅĀS

2. KORONAS IZLĀDES DIVELEKTRODU IERĪCE

O. Vilitis, I. Muzikante, M. Rutkis, A. Vembris

Kopsavilkums

Izstrādāta salīdzinoši vienkārša tehniska ierīce organisko nelineāro optisko (NLO) polimēru polarizēšanai, izmantojot divelektrodu (punkts-plate vai stiepleplate) sistēmu. Polarizācijas norises NLO polimeros pētītas, izmantojot konstantas strāvas pozitīvas koronas polarizēšanas metodi. Piedāvātā eksperimentālā koronas polarizēšanas ierīce nodrošina izlādes strāvu $0,5-3 \mu \mathrm{A}$ pie koronas elektrodiem pieliktā sprieguma $3-12 \mathrm{kV}$, kā arī iespēju izvēlēties dažāda tipa koronas elektrodus.

Plāno kārtinu paraugu polarizēšanas eksperimentālās pārbaudes, kas veiktas, izmantojot aprakstīto polarizēšanas ierīci, liecina, ka pie noteiktas parauga orienttēšanas temperatūras un koronas izlādes strāvas polimeru materiālu divelektrodu koronas polarizēšanas tehnika ir sekmīgi lietojama. Taču, lai iegūtu plašāku informāciju par polarizēšanas un lādinu pārneses procesu dinamiku, vajadzētu izmantot trīselektrodu uzlādes sistēmu - koronas triodi. Šāda ierīce, kā arī mūsu pētîjumu rezultāti par minētajām aktīvajām NLO sistēmām, tiks sniegti žurnāla nākamajā rakstā.

02.01.2012. 